DOI 10.15593/2224-9354/2017.2.13

УДК 336.763 .2

\author{
С.В. Пономарева, И.В. Железнова
}

\title{
ОСОБЕННОСТИ ПРОВЕДЕНИЯ ОБРАТНОГО ВЫКУПА АКЦИЙ КОМПАНИЯМИ В РОССИИ
}

\begin{abstract}
Статья посвящена актуальным аспектам выявления мотивов и особенностей проведения обратного выкупа акций публичным акционерным обществом «Роснефть». Были проанализированы и оценены четыре основных мотива использования обратного выкупа собственных акций компании: сигнал о недооценке акций компании; снижение свободного денежного потока; увеличение финансового рычага; повышение прибыли на акцию. Авторами рассматривались основные цели выкупа компаниями своих собственных акций. Была собрана и обобщена информация о финансовых показателях и мультипликаторах, на основе которых аналитики и инвесторы формируют мнение об успешности функционирования российской компании, о ее справедливой стоимости на рынке, инвестиционной привлекательности. Указан основной фактор (особенность) - владение контрольным пакетом акций компаний государством, который оказывает влияние на принятие важных управленческих решений. Представлено сравнение основных детерминантов, влияющих на релевантные решения о выкупе акций в России и за рубежом. На основе специфичных для России детерминантов выкупа акций представлена динамичная модель их влияния на релевантные управленческие решения. В левой части динамичной модели - внешние эффекты в экономике (экстерналии), а в правой части - внутренние эффекты (интерналии). Авторы отмечают положительные и отрицательные экстернальные эффекты полученных в результате обратного выкупа акций российскими компаниями. В заключение статьи представлены выводы о специфике проведения процедуры buуback на российском рынке, связанной с участием государства в уставном капитале компании.

Ключевые слова: обратный выкуп акций, мотивы, специфика, доля государства, основные финансовые мультипликаторы, справедливая стоимость компании, процедура buy-back.
\end{abstract}

Безусловно, инструменты и процедуры, заимствуемые у прогрессивного рыночного Запада, требуют адаптации к специфике национальной экономики, пережившей переход от плановой экономики к рыночной четверть века назад. Тем не менее использование лучших практик развитых стран и встраивание их в существующие реалии рынка дает толчок к развитию национальной экономики и, как все новаторское и рисковое, дает новые возможности для получения сверхприбылей.

Актуальность темы исследования заключается в том, что зарубежными компаниями применяется процедура обратного выкупа акций, а для России она носит адаптационный характер и контролируется государством [1].

Цель научной статьи - на основе специфичных для России детерминантов выкупа акций создать динамичную модель их влияния на релевантные управленческие решения.

(С) Пономарева С.В., Железнова И.В., 2017

Пономарева Светлана Васильевна - канд. экон. наук, доцент кафедры экономики и финансов ФГБОУ ВО «Пермский национальный исследовательский политехнический университет», e-mail: psvpon@mail.ru.

Железнова Ирина Викторовна - аспирант кафедры экономики и финансов ФГБОУ ВО «Пермский национальный исследовательский политехнический университет», e-mail: honey1805@ya.ru. 
Объектом исследования в данной статье являются экономически значимые предприятия в России (публичные акционерные общества), акции которых котируются на международном финансовом рынке.

Предмет исследования - операции обратного выкупа акций компаниями России.

Основная гипотеза исследования заключается в том, что при применении обобщенных финансовых мультипликаторов и показателей специалистам в области обратного выкупа акций значительно легче будет делать выводы о справедливой стоимости активов компании и о ее рыночной стоимости в целом.

В статье были использованы следующие методы научного познания исследуемого материала: научный, моделирование, дедукция, наблюдение, систематизация и др.

Научная полемика в области обратного выкупа акций компаниями активной стала в 2016 году, в связи с изменениями в законодательстве [1]. Среди ученых, занимающихся этой проблематикой, целесообразно отметить: А.Н. Задорожную [2], Н.М. Сибову [3], К.Е. Кузьмичева [4], которые отмечают в своих научных трудах практический аспект обратного выкупа акций компаниями. А.В. Солопченко рассматривает обратный выкуп акций компании как инструмент управления стоимостью компании [5].

Авторами научной статьи также ранее рассматривались различные аспекты темы исследования, такие как мотивы обратного выкупа акций, российскими компаниями [6], факторы, негативно влияющие на инвестиционную привлекательность организаций [7], оценка справедливой стоимости активов [8] компании. К зарубежным ученым, особенно активно изучающим проблемы обратного выкупа акций, можно отнести: Grullon G., Michaely R. [9], HuaYang [10].

Отметим, что осенью 2016 года масштабный интерес к представленной теме был сконцентрирован вокруг публичного акционерного общества «Роснефть» (далее - ПАО), которая при поддержке Правительства Российской Федерации объявила о намерении выкупить 19,5 \% собственных акций [6].

Однако возникает вопрос, чем был обоснован выбор процедуры по обратному выкупу акций в ПАО «Роснефть».

Существуют четыре основных мотива использования обратного выкупа собственных акций компании:

1) сигнал о недооценке акций компании;

2) снижение свободного денежного потока;

3) увеличение финансового рычага;

4) повышение прибыли на акцию [10].

Более того, обратный выкуп акций для их последующего аннулирования позволяет избежать размытия капитала вследствие эмиссии новых ценных бумаг. 
Согласно российскому законодательству [1], сделка buy-back может осуществляться в следующих случаях [6]:

- выкуп обществом по решению общего собрания акционеров или совета директоров;

- выкуп обществом в случае уменьшения уставного капитала;

- выкуп по требованию акционера в случае реорганизации общества, совершения крупной сделки, внесения изменения в устав (при условии нарушения прав акционера этими актами или при его голосовании против принятия этих актов);

- текущая купля-продажа акций на фондовом рынке [11].

В качестве основных целей выкупа компаниями своих собственных акций можно выделить:

- защиту компании от поглощений;

- передачу акций собственному менеджменту в качестве поощрения;

- превращение компании в закрытое акционерное общество путем изъятия акций из свободного обращения;

- изменение структуры капитала компании;

- инвестирование компанией излишков наличности в собственную стабильность и оптимизацию процессов управления акционерным капиталом;

- использование в качестве одной из форм выплаты дивидендов акционерам;

- избавление от ликвидности, которую компания считает избыточной;

- использование выкупленных акций для оплаты приобретения других компаний;

• улучшение соотношения рыночной цены акции и прибыли на одну акцию [11].

Каждая из указанных целей приобретает лидирующее положение в зависимости от экономической ситуации на рынке. Так, например, в годы высоких цен на нефть доли в компании становятся премиями и средством вложения избыточной наличности. В период дестабилизации экономической ситуации акции становятся «господствующей высотой» в рейдерских атаках.

В табл. 1 приведены основные финансовые показатели, а в табл. 2 - финансовые мультипликаторы, необходимые для расчета справедливой стоимости компании.

На примере сделки buy-back, проведенной компанией «Роснефть», проанализируем каждый из мотивов подробнее и рассчитаем основные финансовые мультипликаторы и показатели [12].

По мнению Роберта Дадли, генерального директора нефтяной компании British Petroleum (далее - ВР), доля акций которых в уставном капитале ПАО «Роснефть» составляет 19,75 \%, стоимость акций пакета компании «Роснефть» вызывает споры, акции компании могут стоить выше ранее озвученных сделок, а значит, акции компании «Роснефть» недооценены [13]. 
Основные финансовые показатели для определения справедливой стоимости компании путем сравнения с аналогами на рынке

\begin{tabular}{|c|c|c|}
\hline $\begin{array}{c}\text { Наименование } \\
\text { финансового показателя } \\
\text { на русском языке }\end{array}$ & $\begin{array}{c}\text { Наименование } \\
\text { финансового показателя } \\
\text { на английском языке }\end{array}$ & $\begin{array}{c}\text { Экономический смысл } \\
\text { и технология расчета } \\
\text { финансовых показателей }\end{array}$ \\
\hline \multicolumn{3}{|c|}{ Показатели первого уровня } \\
\hline Рыночная капитализация & Market Capitalization & $\begin{array}{l}\text { Отражает рыночную } \\
\text { стоимость компании }\end{array}$ \\
\hline Общая стоимость активов & Total assets & $\begin{array}{l}\text { Отражает суммарную } \\
\text { стоимость активов }\end{array}$ \\
\hline Стоимость компании & Enterprise Value & $\begin{array}{l}\text { Рыночная стоимость компании + } \\
\text { долг компании - денежные } \\
\text { средства и их эквиваленты }\end{array}$ \\
\hline Выручка & Revenue & $\begin{array}{l}\text { Объем поступивших средств } \\
\text { от продажи продукции за оп- } \\
\text { ределенный период времени }\end{array}$ \\
\hline Чистая прибыль/убыток & Net profit/loss & $\begin{array}{l}\text { Все доходы - все расходы - } \\
\text { текущий налог на прибыль }\end{array}$ \\
\hline Денежный поток & Cash flow & $\begin{array}{l}\text { Отражает положительную } \\
\text { и отрицательную разницу } \\
\text { между величинами поступ- } \\
\text { лений и выплат денежных } \\
\text { средств за определенный } \\
\text { период времени } \\
\end{array}$ \\
\hline \multicolumn{3}{|c|}{ Показатели второго уровня } \\
\hline $\begin{array}{l}\text { Прибыль до уплаты нало- } \\
\text { гов, процентов по кредитам } \\
\text { и амортизации }\end{array}$ & $\begin{array}{l}\text { Earnings Before Interest \& } \\
\text { Taxes, Depreciation and } \\
\text { Amortization (EBITDA) }\end{array}$ & $\begin{array}{l}\text { Используется при расчете } \\
\text { финансовых мультипликато- } \\
\text { ров, позволяет оценить при- } \\
\text { быльность компании } \\
\end{array}$ \\
\hline $\begin{array}{l}\text { Прибыль до уплаты нало- } \\
\text { гов, процентов по кредитам }\end{array}$ & $\begin{array}{l}\text { Earnings Before Interest \& } \\
\text { Taxes (EBIT) }\end{array}$ & $\begin{array}{l}\text { Отражает прибыль компании } \\
\text { до уплаты налогов и процен- } \\
\text { тов по кредитам } \\
\end{array}$ \\
\hline Прибыль до налогов ЕВТ & $\begin{array}{l}\text { Earnings Before Taxes } \\
\text { (EBT) }\end{array}$ & $\begin{array}{l}\text { Отражает доналоговую или } \\
\text { валовую прибыль компании }\end{array}$ \\
\hline
\end{tabular}


Таблица 2

Основные финансовые мультипликаторы и технология их расчета

\begin{tabular}{|c|c|c|c|}
\hline \begin{tabular}{|c|} 
Краткое \\
наименование \\
мультипликатора \\
\end{tabular} & $\begin{array}{c}\text { Наименование } \\
\text { мультипликатора } \\
\text { на английском языке }\end{array}$ & $\begin{array}{c}\text { Характеристика } \\
\text { финансовых } \\
\text { мультипликаторов }\end{array}$ & $\begin{array}{c}\text { Экономический смысл } \\
\text { мультипликатора }\end{array}$ \\
\hline $\mathrm{P} / \mathrm{E}$ & $\begin{array}{l}\text { Price per share/ Earn- } \\
\text { ing per share }\end{array}$ & \begin{tabular}{|l} 
Коэффициент отно- \\
шения капитализа- \\
ции к годовому объ- \\
ему чистой прибыли
\end{tabular} & $\begin{array}{l}\text { Мультипликатор от- } \\
\text { ражает, какое количе- } \\
\text { ство лет понадобится } \\
\text { компании при текущем } \\
\text { размере годовой чис- } \\
\text { той прибыли, чтобы } \\
\text { окупить себя }\end{array}$ \\
\hline EPS & Earning per share & $\begin{array}{l}\text { Коэффициент дохо- } \\
\text { да на одну акцию }\end{array}$ & $\begin{array}{l}\text { Отношение объема } \\
\text { годовой чистой при- } \\
\text { были компании (за } \\
\text { вычетом дивидендов } \\
\text { по привилегирован- } \\
\text { ным акциям) к средне- } \\
\text { му числу обращаю- } \\
\text { щихся акций }\end{array}$ \\
\hline $\mathrm{P} / \mathrm{S}$ & $\begin{array}{l}\text { Price per share/Sales } \\
\text { per share }\end{array}$ & $\begin{array}{l}\text { Коэффициент отно- } \\
\text { шения капитализа- } \\
\text { ции к годовому объ- } \\
\text { ему выручки }\end{array}$ & $\begin{array}{l}\text { Универсальный фи- } \\
\text { нансовый мультипли- } \\
\text { катор }\end{array}$ \\
\hline $\mathrm{P} / \mathrm{CF}$ & $\begin{array}{l}\text { Price per share/Cash } \\
\text { Flow }\end{array}$ & $\begin{array}{l}\text { Коэффициент отно- } \\
\text { шения капитализа- } \\
\text { ции к денежному } \\
\text { потоку }\end{array}$ & \begin{tabular}{|l} 
Универсальный фи- \\
нансовый мультипли- \\
катор. Отражает, какая \\
часть денежного пото- \\
ка, генерируемого \\
компанией, приходит- \\
ся на чистую прибыль
\end{tabular} \\
\hline EV/EBITDA & $\begin{array}{l}\text { Enterprise Val- } \\
\text { ue/Earnings Before } \\
\text { Interest \& Taxes, De- } \\
\text { preciation and Amor- } \\
\text { tization (EBITDA) }\end{array}$ & \begin{tabular}{|l|} 
Коэффициент отно- \\
шения стоимости \\
компании к прибыли \\
до уплаты налогов, \\
процентов по креди- \\
там, амортизации \\
\end{tabular} & $\begin{array}{l}\text { Мультипликатор объ- } \\
\text { ективно отражает } \\
\text { стоимость объекта } \\
\text { оценки (компании) }\end{array}$ \\
\hline EV/EBIT & $\begin{array}{l}\text { Enterprise Val- } \\
\text { ue/Earnings Before } \\
\text { Interest \& Taxes }\end{array}$ & $\begin{array}{l}\text { Коэффициент отно- } \\
\text { шения стоимости } \\
\text { компании к опера- } \\
\text { ционной прибыли }\end{array}$ & $\begin{array}{l}\text { Мультипликатор может } \\
\text { применяться при огра- } \\
\text { ниченной информации } \\
\text { о компаниях-аналогах, } \\
\text { когда по объекту } \\
\text { оценки и объектам- } \\
\text { аналогам известны } \\
\text { выручка, прибыль } \\
\text { до налогообложения } \\
\end{array}$ \\
\hline
\end{tabular}


Окончание табл. 2

\begin{tabular}{|c|c|c|c|}
\hline $\begin{array}{c}\text { Краткое } \\
\text { наименование } \\
\text { мультипликатора }\end{array}$ & $\begin{array}{c}\text { Наименование } \\
\text { мультипликатора } \\
\text { на английском языке }\end{array}$ & $\begin{array}{c}\text { Характеристика } \\
\text { финансовых } \\
\text { мультипликаторов }\end{array}$ & $\begin{array}{c}\text { Экономический смысл } \\
\text { мультипликатора }\end{array}$ \\
\hline $\mathrm{EV} / \mathrm{S}$ & Enterprise Value/Sales & $\begin{array}{l}\text { Коэффициент отно- } \\
\text { шения стоимости } \\
\text { компании к объему } \\
\text { продаж }\end{array}$ & $\begin{array}{l}\text { Рассчитывается и ис- } \\
\text { пользуется аналогично } \\
\text { показателю EV/EBIT. } \\
\text { Универсальный фи- } \\
\text { нансовый мультипли- } \\
\text { катор }\end{array}$ \\
\hline $\mathrm{D} / \mathrm{E}$ & Debt-to-equity ratio & $\begin{array}{l}\text { Коэффициент соот- } \\
\text { ношения собствен- } \\
\text { ного и заемного ка- } \\
\text { питала (левередж) }\end{array}$ & $\begin{array}{l}\text { Используется для фи- } \\
\text { нансирования активов } \\
\text { компании. Тесно свя- } \\
\text { зан с заемным капита- } \\
\text { лом компании }\end{array}$ \\
\hline ROA & Return on Assets & $\begin{array}{l}\text { Коэффициент рента- } \\
\text { бельности активов }\end{array}$ & $\begin{array}{l}\text { Отношение чистой } \\
\text { прибыли к общей } \\
\text { стоимости активов } \\
\text { компании. Позволяет } \\
\text { оценить, какова эко- } \\
\text { номическая эффектив- } \\
\text { ность (рентабельность) } \\
\text { активов, находящихся } \\
\text { на балансе компании }\end{array}$ \\
\hline ROE & Return on Earninng & $\begin{array}{l}\text { Коэффициент рента- } \\
\text { бельности акцио- } \\
\text { нерного капитала }\end{array}$ & $\begin{array}{l}\text { Отношение чистой } \\
\text { прибыли компании к } \\
\text { общей стоимости чис- } \\
\text { тых активов. Позволя- } \\
\text { ет оценить, какова } \\
\text { экономическая эффек- } \\
\text { тивность (рентабель- } \\
\text { ность) акционерного } \\
\text { капитала }\end{array}$ \\
\hline ROS & Return on Sales & $\begin{array}{l}\text { Коэффициент рента- } \\
\text { бельности продаж }\end{array}$ & $\begin{array}{l}\text { Отношение прибыли } \\
\text { от продаж к объему } \\
\text { выручки }\end{array}$ \\
\hline
\end{tabular}

Более того, в подтверждение несправедливой стоимости акций ПАО НК «Роснефть» в соответствии с Распоряжением Правительства Российской Федерации от 10 октября 2016 года завершило корпоративные мероприятия по подготовке и осуществлению приобретения государственного пакета акций ПАО АНК «Башнефть», составляющего 50,08 \% уставного капитала компании. 12 октября 2016 года ПАО НК «Роснефть» полностью выполнило свои обязательства по договору купли-продажи порядка 89 млн акций ПАО АНК «Башнефть» по цене 329,69 млрд руб. [13].

Кроме того, вследствие слияния компаний ожидался синергетический эффект, который позволил нарастить капитализацию самой компании «Рос- 
нефть». Покупка акций «Башнефть» являлась значимым событием, после которого необходима переоценка акций компании «Роснефть».

Следовательно, на период подготовки к процедуре обратного выкупа акции компании «Роснефть» были недооценены по причине произошедших существенных событий, и сама по себе сделка buy-back являлась дополнительным сигналом о недооценке акций компании. Тем не менее приобретение компании «Башнефть» было необходимо для увеличения привлекательности ПАО «Роснефть» со стороны внешних потенциальных инвесторов, а также способствовало расширению влияния компании «Роснефть» в нефтяной отрасли.

Поскольку непосредственно перед выкупом произошел ряд существенных событий, таких как покупка акций компании «Башнефть» на сумму 329,69 млрд руб., продажа 11 \% АО «Ванкорнефть» на сумму 59 млрд руб. и др., можно заключить, что у компании «Роснефть» имелся избыток наличности притом, что на 30.09.2016 г. денежные средства и их эквиваленты в консолидированном балансе компании составляли 787 млрд руб., в то время как объем денежных средств за аналогичный период 2015 и 2014 годов составил порядка 657 и 139 млрд руб. соответственно. Следовательно, этот мотив имеет место быть в данной сделке, так как за 2 года компания увеличила объем наличности в 5,7 раза [13].

Исходя из динамики финансового рычага D/E компании «Роснефть» (табл. 3) можно заключить, что в целом компания старалась поддерживать соотношение собственных и заемных средств примерно 50/50, на протяжении 2015 года уровень долга несколько превышал величину собственного капитала, хотя в 2016 году заметно снижение финансового рычага в сторону увеличения собственного капитала. При этом долгосрочные и краткосрочные займы компания «Роснефть» берет в основном для финансирования целевой хозяйственной деятельности, однако процедура обратного выкупа осуществлялась за счет собственных средств компании и привлеченного кредитного финансирования, организованного одним из крупнейших европейских банков [14].

Таблица 3

Динамика финансового рычага D/E

за период с 30.09.2014 по 30.09.2016 (расчеты авторов)

\begin{tabular}{|l|c||l|c|}
\hline \multicolumn{1}{|c|}{ Дата } & $\mathrm{D} / \mathrm{E}$ & \multicolumn{1}{|c|}{ Дата } & $\mathrm{D} / \mathrm{E}$ \\
\hline 30.09 .2014 & 0,77 & 31.12 .2015 & 1,15 \\
\hline 31.03 .2015 & 1,13 & 31.03 .2016 & 1,066 \\
\hline 30.06 .2015 & 0,99 & 30.06 .2016 & 0,956 \\
\hline 30.09 .2015 & 1,087 & 30.09 .2016 & 0,928 \\
\hline
\end{tabular}

Таким образом, сделка buy-back должна снизить величину собственного капитала и как в 2015 году сбалансировать соотношение финансового левереджа, однако в масштабах крупного холдинга проведение обратного выкупа 
именно с целью увеличения финансового рычага не прослеживается, так как в 2014 году наблюдался более низкий показатель D/E.

Наблюдение за изменениями мультипликатора P/E (табл. 4) приводит к заключению, что соотношение цены на акцию к чистой прибыли на акцию не имеет определенного тренда, однако в результате совершения обратного выкупа данный показатель улучшится, что повысит инвестиционную привлекательность компании.

Таблица 4

Динамика финансового мультипликатора P/E за период с 30.09.2014 по 30.09.2016 (расчеты авторов)

\begin{tabular}{|c|c||c|c|}
\hline Дата & P/E & \multicolumn{1}{|c|}{ Дата } & P/E \\
\hline 30.09 .2014 & - & 31.12 .2015 & 27,38 \\
\hline 31.03 .2015 & 47,76 & 31.03 .2016 & 231,21 \\
\hline 30.06 .2015 & 18,35 & 30.06 .2016 & 39,29 \\
\hline 30.09 .2015 & 22,98 & 30.09 .2016 & 139,92 \\
\hline
\end{tabular}

Как видно, процедура обратного выкупа акций, рассмотренная на примере компании ПАО «Роснефть», улучшает основные финансовые мультипликаторы, на основе которых аналитики и инвесторы формируют мнение об успешности функционирования компании, что повышает ее инвестиционную привлекательность.

Кроме того, четыре основных мотива универсальны для любого публичного акционерного общества. Однако уникальной нашумевшую в новостях сделку по обратному выкупу акций ПАО «Роснефть» делает то, что контрольным пакетом компании в размере 69,5 \% владеет государство через АО «Роснефтегаз» [14], а значит, процедура обратного выкупа в рассматриваемой ситуации приобретает черты приватизации, т.е. фактически «Роснефть» скупает собственные акции у акционера «Роснефтегаз», которым в доле 100 \% владеет государство.

Тем не менее процедура обратного выкупа была необходима для того, чтобы впоследствии продать 19,5 \% акций компании «Роснефть» стоимостью 692 млрд руб. консорциуму инвесторов, которым в равных долях владеют фонд Qatar Investment Authority и швейцарский трейдер Glencore, поэтому buy-back явился лишь первым этапом сделки по приватизации, т.е. продажи государственной собственности частным собственникам, 19,5\% акций ПАО «Роснефть» [15].

Изначально выкуп акций самой «Роснефтью» был «резервным вариантом», он был нужен скорее для подстраховки бюджета и не был особо нужен самой компании [16]. Состав акционеров ПАО НК «Роснефть», владеющих более $5 \%$ уставного капитала [17], указан на официальном сайте компании, так как информация должна быть открыта внешним пользователям финансовой отчетности. 
Таким образом, в качестве подготовительного этапа к продаже пакета акций иностранным инвесторам была выбрана именно процедура buy-back, поскольку в отличие от дополнительной эмиссии ценных бумаг, обратный выкуп не снижает долю государства в уставном капитале. Более того, приобретение актива «Башнефть», а также сигнал о недооценке акций компании, снижение свободного денежного потока, баланс финансового рычага, увеличение прибыли на акцию, которые следуют в результате обратного выкупа акций, повышают привлекательность компании для внешних инвесторов и позволяют дороже продать бумаги компании.

С точки зрения финансовых показателей и конъюнктуры рынка обратный выкуп акций компании «Роснефть» был проведен в нужное время, когда акции были недооценены рынком из-за синергетического эффекта, компания за 2 года накопила достаточный объем наличности, у компании несколько снизился финансовый рычаг, компания увеличила прибыль на акцию, что позволило выгодно завершить крупную сделку.

Рассмотрим основные детерминанты, оказывающие влияние на релевантные решения ведущих специалистов экономически значимых компаний об обратном выкупе акций (используя зарубежный опыт) (рисунок).

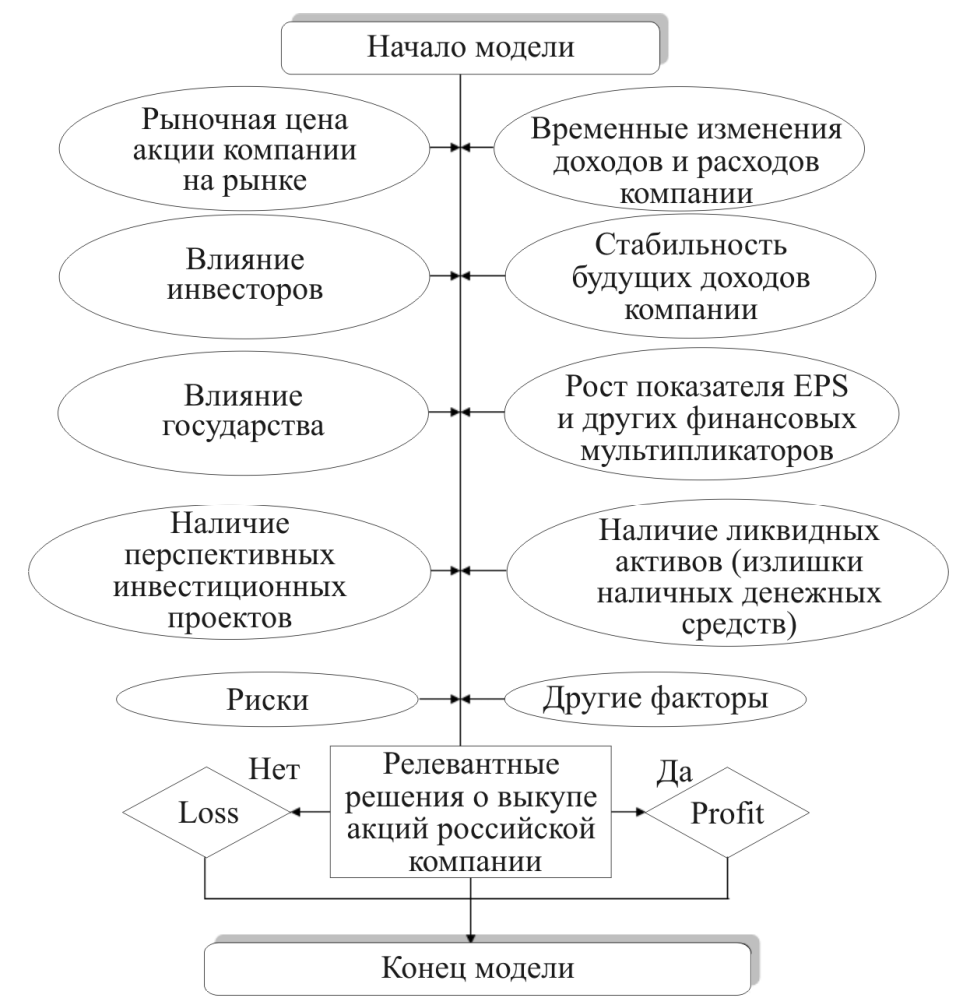

Рис. Динамичная модель принятия управленческого решения об обратном выкупе акций российскими компаниями, с учетом действующих детерминантов 
Представленная авторами динамичная модель принятия управленческих решений об обратном выкупе акций российскими компаниями с учетом действующих в стране детерминантов должна использоваться на базе точных расчетов основных финансовых мультипликаторов и показателей, представленных в табл. 1 и 2. Данные расчеты дают обоснованное представление о справедливой стоимости компании на рынке. В левой части динамичной модели (см. рисунок) представлены внешние эффекты в экономике (экстерналии), они носят как положительный характер (наличие перспективных инвестиционных проектов), так и отрицательный (риски). В правой части динамичной модели представлены внутренние эффекты (интерналии).

Заключение. Следует отметить, что особенностью процедуры обратного выкупа в России является присутствие государства в уставном капитале российских компаний, таких как ПАО «ФСК ЕЭС» (80,72 \%) [18], «Транснефть» $(78,1 \%)$ [19], ПАО «ВТБ» (60,93 \%) [20], ПАО «РусГидро» (66,84 \%) [21], ПАО «Сбербанк» $(57,58$ \%) [22], ПАО «Аэрофлот» $(51,17 \%)$ [23], ПАО «Газпром» (50,23\%) [24], поэтому кроме благоприятных последствий после завершения сделок buy-back для выгодной продажи стратегическим инвесторам выбор процедуры обратного выкупа может быть сделан ввиду сохранения или увеличения доли государства в уставном капитале компаний, с целью сохранения или расширения влияния государства в компании и отрасли.

\section{Список литературы}

1. Об акционерных обществах [Электронный ресурс]: Федер. закон от 26.12.1995 г. № 208-Ф3 (ред. от 03.07.2016 г.) (с изм. и доп., вступ. в силу с 01.09.2016 г.). - URL: http://www.consultant.ru/document/cons_doc_LAW_8743/ (дата обращения: 20.12.2016).

2. Задорожная А.Н. Практика обратного выкупа акций российскими компаниями // Финансовая аналитика: проблемы и решения. - 2016. - № 42 (324). C. $13-26$.

3. Сибова Н.М. Практика обратного выкупа акций // Управление экономическими системами: электрон. науч. журн. - 2013. - № 4 (52). - С. 3.

4. Кузьмичев К.Е. Исследование обратного выкупа акций российскими компаниями // Вопросы новой экономики. - 2012. - № 4 (24). - С. 20-24.

5. Солопченко А.В. Обратный выкуп акций российскими акционерными обществами как инструмент управления стоимостью компаний: законодательный аспект // Молодой ученый. - 2016. - № 15 (119). - С. 319.

6. Железнова И.В. Мотивы обратного выкупа акций российскими компаниями // Экономика и управление: проблемы, решения. - 2016. - № 4. - С. 195-204.

7. Пономарева С.В., Мельникова А.С. Факторы, негативно влияющие на инвестиционную привлекательность организаций Пермского края // Вестник Пермского национального исследовательского политехнического университета. Социально-экономические науки. - 2016. - № 2. - С. 193-208. 
8. Пономарева С.В., Климова Е.К. Оценка справедливой стоимости активов как возможность повышение инвестиционной привлекательности предприятия // Экономика и предпринимательство. - 2016. - № 3-2 (68-2). - С. 577-581.

9. Grullon G., Michaely R. Dividends, Repurchases, and the Substitution Hypothesis // Journal of Finance. - 2002. - Vol. 57, iss. 4. - P. 1649-1684. DOI: $10.1111 / 1540-6261.00474$

10. Hua Yang. A Re-examanation of Stock Repurchase in USA // Doctor of Philisophy. - Old Dominion University, August 2010.

11. Богданов И. О спорах, связанных с выкупом акционерным обществом собственных акций // Слияния и Поглощения. - 2009. - № 6 (76). - С. 55-59.

12. Анализ руководством финансового состояния и результатов деятельности компании за 3 месяца, завершившихся 30 сентября и 30 июня 2016 года, и за 9 месяцев, завершившихся 30 сентября 2016 и 2015 годов [Электронный ресурс]. - URL: https://www.rosneft.ru/upload/site1/document_cons_ report/MDA_RUS_3Q2016 (дата обращения: 19.12.2016).

13. Глава ВР назвал акции «Роснефти» недооцененными [Электронный pecypc]. - URL: https://rg.ru/2016/10/18/glava-vr-nazval-akcii-rosnefti-nedoocenennymi.html (дата обращения: 19.12.2016).

14. «Роснефть» проведет buyback, если инвесторы не приобретут акции [Электронный ресурс]. - URL: https://ria.ru/economy/20161026/1480050768.html (дата обращения: 19.12.2016).

15. «Роснефть» раскрыла детали сделки по продаже 19,5 \% акций [Электронный pecypc]. - URL: http://www.rbc.ru/economics/10/12/2016/ 584c58e89a7947ec70b5e46f (дата обращения: 19.12.2016).

16. Сечин продал «Роснефть» иностранным инвесторам [Электронный pecypc]. - URL: https://www.vedomosti.ru/business/articles/2016/12/07/668663rosneft (дата обращения: 19.12.2016).

17. Состав акционеров (держателей акций) ПАО «НК «Роснефть», владеющих более 5 \% уставного капитала Компании по состоянию на 1 декабря 2016 г. [Электронный ресурc]. - URL: https://www.rosneft.ru/Investors/ structure/share_capital/ (дата обращения: 19.12.2016).

18. Официальный сайт ПАО «ФСК ЕЭС». Информация о структуре акционерного капитала ПАО «ФСК ЕЭС». - URL: http://www.fskees.ru/shareholders_and_investors/information_on_shares/shareholding_structure/ (дата обращения: 26.12.2016).

19. Официальный сайт «Транснефть». Структура держателей акций. - URL: https://www.conomy.ru/emitent/transneft/trnfp-ak (дата обращения: 26.12.2016).

20. Официальный сайт ПАО «ВТБ». Список лиц, под контролем либо значительным влиянием которых находится банк. - URL: http://www.vtb.ru/ upload/iblock/949/rb1000_-bez-podpisi.pdf (дата обращения: 26.12.2016). 
21. Официальный сайт ПАО «РусГидро». Список лиц, владеющих более чем $5 \%$ уставного капитала ПАО «РусГидро» по состоянию на 30 ноября 2016 года. - URL: http://www.rushydro.ru/investors/stockmarket/capital/ (дата обращения: 26.12.2016).

22. Официальный сайт ПАО «Сбербанк». Структура акционеров: статистика 2014-2016 гг. - URL: http://www.sberbank.com/common/img/uploaded/ files/pdf/stockholders/Izmenenie_struktury_aktsionerov_Sberbanka_2014-2016.pdf (дата обращения: 26.12.2016).

23. Официальный сайт ПАО «Аэрофлот». Структура акционерного капитала. - URL: http://ir.aeroflot.ru/securities/shareholder-capital/ (дата обращения: 26.12.2016).

24. Официальный сайт ПАО «Газпром». Структура акционерного капитала ПАО «Газпром». - URL: http://www.gazprom.ru/investors/structure/ (дата обращения: 26.12.2016).

\section{References}

1. Ob aktsionernykh obshchestvakh: Feder. zakon ot 26.12.1995 g. № 208-FZ (red. ot 03.07.2016 g.) (s izm. i dop., vstup. v silu s 01.09.2016 g.) [On joint stock companies: Federal law of 26.12.1995, No. 208-FZ (as amended on 03 July 2016) (as amended, supplemented entered into force on 01 September 2016).]. Available at: http://www.consultant.ru/document/cons_doc_LAW_8743/(accessed 20 December 2016).

2. Zadorozhnaia A.N. Praktika obratnogo vykupa aktsii Rossiiskimi kompaniiami [The practice of Russian companies share buybacks]. Finansovaia analitika: problemy i resheniia, 2016, no. 42, vol. 324, pp. 13-26.

3. Sibova N.M. Praktika obratnogo vykupa aktsii [Practice of share buyback]. Upravlenie ekonomicheskimi sistemami: elektron. nauch. zhurn., 2013, no. 4, vol. 52, p. 3.

4. Kuz'michev K.E. Issledovanie obratnogo vykupa aktsii rossiiskimi kompaniiami [Investigation of Russian companies share buybacks]. Voprosy novoi ekonomiki, 2012, no. 4, vol. 24, pp. 20-24.

5. Solopchenko A.V. Obratnyi vykup aktsii rossiiskimi aktsionernymi obshchestvami kak instrument upravleniia stoimost'iu kompanii: zakonodatel'nyi aspekt [Russian joint-stock companies share buybacks as a tool of managing the company's value: legislative aspect]. Molodoi uchenyi, 2016, no. 15, vol. 119, p. 319.

6. Zheleznova I.V. Motivy obratnogo vykupa aktsii rossiiskimi kompaniiami [Motives for the Russian companies share buybacks]. Ekonomikaiupravlenie: problemy, resheniia, 2016, no. 4, pp. 195-204.

7. Ponomareva S.V., Mel'nikova A.S. Faktory, negativno vliiaiushchie na investitsionnuiu privlekatel'nost' organizatsii Permskogo kraia [Factors affecting the investment attractiveness of Perm Krai organizations]. PNRPU Sociology and Economics Bulletin, 2016, no. 2, pp. 193-208.

8. Ponomareva S.V., Klimova E.K. Otsenka spravedlivoi stoimosti aktivov kak vozmozhnost' povyshenie investitsionnoi privlekatel'nosti predpriiatiia [Estimation of 
assets fair value as an opportunity to increase the investment attractiveness of an enterprise]. Ekonomika i predprinimatel'stvo, 2016, no. 3-2, vol. 68-2, pp. 577-581.

9. Grullon G., Michaely R. Dividends, repurchases, and the substitution hypothesis. Journal of Finance, 2002, pp. 1649-1684.

10. Hua Yang. A Re-examanation of stock repurchase in USA. Doctor of Philosophy, Old Dominion University Publ., August 2010.

11. Bogdanov I. O sporakh, sviazannykh s vykupom aktsionernym obshchestvom sobstvennykh aktsii [On disputes related to share buybacks by the joint-stock companies of their own shares]. Sliianiia i Pogloshcheniia, 2009, no. 6, vol. 76, pp. 55-59.

12. Analiz rukovodstvom finansovogo sostoianiia i rezul'tatov deiatel'nosti kompanii za 3 mesiatsa, zavershivshikhsia 30 sentiabria i 30 iiunia 2016 goda i za 9 mesiatsev, zavershivshikhsia 30 sentiabria 2016 i 2015 godov [Management analysis of company's financial condition and performance for three months till 30 September and 30 June 2016 and the analysis for nine months till 30 September 2016 and 2015]. Available at: https://www.rosneft.ru/upload/site1/document_cons_ report/MDA_RUS_3Q2016 (accessed 19 December 2016).

13. Glava BP nazval aktsii "Rosnefti" nedootsenennymi [BP CEO calls Rosneft shares undervalued]. Available at: https://rg.ru/2016/10/18/glava-vrnazval-akcii-rosnefti-nedo-ocenennymi.html (accessed 19 December 2016).

14. "Rosneft"' provedet buyback, esli investory ne priobretut aktsii [Rosneft to hold a buyback if investors do not purchase the shares]. Available at: https://ria.ru/economy/20161026/1480050768.html (accessed 19 December 2016).

15. "Rosneft"' raskryla detali sdelki po prodazhe 19,5\% aktsii [Rosneft discloses details of the deal to sell $19.5 \%$ of shares]. Available at: http://www.rbc.ru/economics/ 10/12/2016/584c58e89a7947ec70b5e46f (accessed 19 December 2016).

16. Sechin prodal "Rosneft"' inostrannym investoram [Sechin sells Rosneft to foreign investors]. Available at: https://www.vedomosti.ru/business/articles/2016/ 12/07/668663-rosneft (accessed 19 December 2016).

17. Sostav aktsionerov (derzhatelei aktsii) PAO "NK "Rosneft", vladeiushchikh bolee $5 \%$ ustavnogo kapitala Kompanii po sostoianiiu na 1 dekabria 2016 g. [Shareholders structure of PJSC NK Rosneft holding more than 5\% of the company's authorized capital as of 1 December, 2016]. Available at: https://www.rosneft.ru/Investors/ structure/share_capital/ (accessed 19 December 2016).

18. Ofitsial'nyi sait PAO "FSK EES". Informatsiia o strukture aktsionernogo kapitala PAO "FSK EES" [Official website of PJSC FGC UES. Information about the structure of PJSC FGC UES share capital]. Available at: http://www.fskees.ru/shareholders_and_investors/information_on_shares/shareholding_structure/ (accessed 26 December 2016).

19. Ofitsial'nyi sait "Transneft"'. Struktura derzhatelei aktsii [Official website of Transneft. Shareholders' composition]. Available at: https://www.conomy.ru/emitent/ transneft/trnfp-ak (accessed 26 December 2016).

20. Ofitsial'nyi sait PAO "VTB". Spisok lits, pod kontrolem libo znachitel'nym vliianiem kotorykh nakhoditsia bank [Official website of PJSC VTB. List of persons 
who control or have significant influence on the bank]. Available at: http://www.vtb.ru/ upload/iblock/949/rb1000_-bez-podpisi.pdf (accessed 26 December 2016).

21. Ofitsial'nyi sait PAO "RusGidro". Spisok lits, vladeiushchikh bolee chem 5\% ustavnogo kapitala PAO "RusGidro" po sostoianiiu na 30 noiabria 2016 goda [List of persons owning more than 5\% of the authorized capital of PJSC RusHydro as of November 30, 2016]. Available at: http://www.rushydro.ru/investors/stockmarket/capital/ (accessed 26 December 2016).

22. Ofitsial'nyi sait PAO “Sberbank”. Struktura aktsionerov: statistika 2014-2016 gg. [Official website of PAO Sberbank. The structure of share capital: 2014-2016 statistics]. Available at: http:/www.sberbank.com/common/img/uploaded/files/pdf/stockholders/ Izmenenie_struktury_aktsionerov_Sberbanka_2014-2016.pdf(accessed 26 December 2016).

23. Ofitsial'nyi sait PAO "Aeroflot". Struktura aktsionernogo kapitala [Official website of PJSC Aeroflot. The structure of share capital]. Available at: http://ir.aeroflot.ru/securities/shareholder-capital/ (accessed 26 December 2016).

24. Ofitsial'nyi sait PAO "Gazprom". Struktura aktsionernogo kapitala PAO "Gazprom" [Official website of PJSC Gazprom. The structure of PJSC Gazprom share capital]. Available at: http://www.gazprom.ru/investors/structure/ (accessed 26 December 2016).

Оригинальность статьи - $81 \%$

Получено 30.12.2016

\section{S.V. Ponomaryova, I.V. Zheleznova}

\section{FEATURES OF SHARE BUYBACKS IN RUSSIA}

The article is devoted to the current aspects of defining the motives and particularities of share buybacks by the public joint-stock company "Rosneft". It analyzes and evaluates the four major motives for share buybacks, such as undervaluation of company's shares, free cash flow depression, capital leverage increase and earnings per share ration advance. The authors consider the major purposes for share buybacks and generalize the data on financial indexation and multipliers, on the basis of which the analytics and investors form their opinion about the company's performance success, as well as about its fair value and investment prospects. The research denotes the majority of the company's shares holding by the government as the major factor that influences key management decision making. The paper presents the comparison of the key determinants that influence relevant decisions on share buyback, both in Russia and abroad. The article presents the dynamic model of share buyback influence on major management decisions, on the basis of specific buyback determinants in Russia. The left part of the dynamic model represents externalities, while the right part demonstrates internalities. The authors mark the positive and negative externalities as a result of share buybacks by the Russian companies. The conclusion presents implications on the features of share buybacks at the Russian stock market, which is characterized by government participation in company's registered capital formation.

Keywords: share buybacks, motives, features, government share, key financial multipliers, fair value, share buybacks procedure.

Svetlana V. Ponomaryova - Candidate of Economic Sciences, Associate Professor, Dept. of Economics and Finance, Perm National Research Polytechnic University, e-mail: psvpon@mail.ru.

Irina V. Zheleznova - Postgraduate Student, Dept. of Economics and Finance, Perm National Research Polytechnic University, e-mail: ho-ney1805@ya.ru. 